\title{
Unilateral Oculomotor Nerve Palsy from Chronic Subdural Hematoma: Case report and Review of the Literature
}

\author{
Zigouris Andreas* and Voulgaris Spyridon \\ Department of Neurosurgery, University Hospital of Ioannina, Greece
}

Submission: September 23, 2016; Published: November 09, 2016

*Corresponding author: Zigouris Andreas, Department of Neurosurgery, University Hospital of Ioannina, Greece, Tel: 302651099701; Email: andzy76@hotmail.com

\section{Abstract}

Chronic subdural hematoma with isolated $3^{\text {rd }}$ cranial nerve palsy was detected in a patient who received an antiplatelet agent. He was operated and after surgery had an immediate resolution of palsy. The proposed mechanism of the reversible $3^{\text {rd }}$ nerve palsy was a compression to the left uncus and moreover a microvascular infarction of the nerve due to mechanical reason, that is rarely observed in this type of intracranial hematomas.

Keywords: Chronic subdural hematoma; $3^{\text {rd }}$ cranial nerve palsy; Antiplatelet agent; Reversible $3^{\text {rd }}$ nerve palsy

\section{Introduction}

Chronic subdural hematoma is a common result after a mild to moderate head injury, especially in elderly who received anticoagulant agents [1,2]. There is a broad spectrum of signs and symptoms, from a mild headache, hemiparesis to comatose patient. Cranial nerve palsies from a chSDH as initial symptoms are uncommon. Pupil-sparing oculomotor nerve palsy with chSDH was described first time from Crone KR et al in a patient with adult-onset diabetes mellitus [3]. Isolated $3^{\text {rd }}$ cranial nerve palsy from bilateral chSDH was first published from Phookan et al, who described an immediate resolution of palsy after surgery (4). In our study we report a bilateral chSDH which caused a unilateral oculomotor palsy in a patient who received an ant platelet agent.

\section{Case Report}

An 83-year old man with a recent history of anti platelet agent administration suffered from a mild headache after a minor head injury two months before. The last two days his daughter observed a left ptosis and a progressive left hemi paresis. He came to our hospital, where the neurologic examination included GCS: 15, 4/5 left hemi paresis and a leftptosis with a slight anisocoria. The CT scan showed a bilateral chronic subdural hematoma (chSDH) (Figure 1). He underwent an urgent evacuation of hematomas through 4 burr holes, frontal and parietal under general anesthesia. Hematomas had a very high pressure. We inserted bilaterally from parietal burr holes two drainages, which were removed after 48 hours. The ptosis and the hemi paresis resolved immediately, 12 hours after surgery. The proposed mechanism of the reversible 3rd nerve palsy was a compression to the left uncus and moreover to the left oculomotor nerve in the ambient cistern. The patient left our department after 2 days and he returned to his normal life and activities without any neurological deficit.

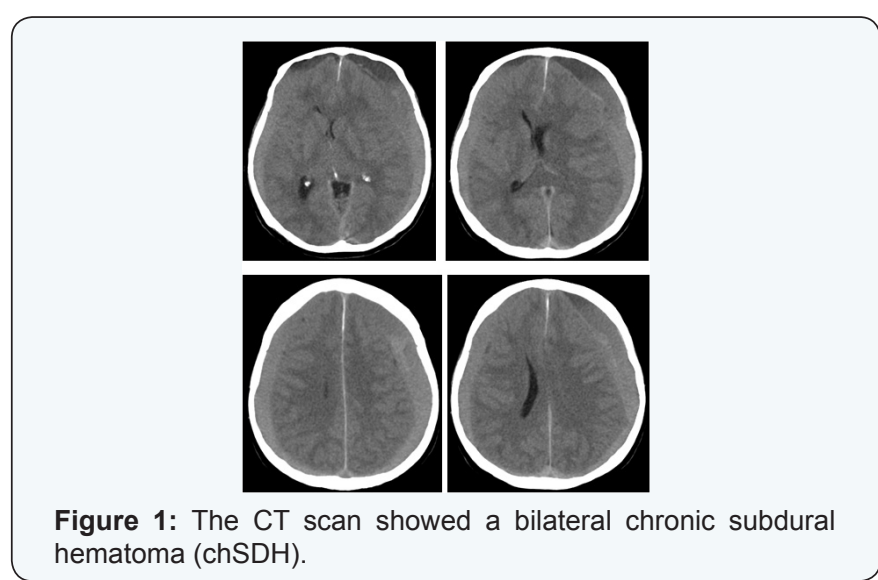




\section{Open Access Journal of Neurology \& Neurosurgery}

\section{Discussion}

chSDH in elderly is the most common hematoma after a head injury, especially in case who received any form of anticoagulants. Bilateral chSDH create a new intracranial environment, where there exists a different balance, which is more fragile. The time of disturbance causes various symptoms and signs. A unique feature is unilateral $3^{\text {rd }}$ cranial nerve palsy. According to this clinical entity a few cases of oculomotor palsy as an initial symptom of a chSDH was published the last 30 years [3-5]. The herniation of uncus in cases of intracranial hypertension compress directly the oculomotor nerve and mesencephalic structures, resumed to anisocoria and coma. The differential diagnosis of a conscious patient with anisocoria includes diabetes mellitus, hypertension, atherosclerosis, collagen vascular disease, intracranial aneurysm, particularly of the posterior communicating artery, cavernous sinus thrombosis [4-8]. The mechanism in all cases is microvascular infarction of the nerve due to a mechanical or pathological reason.

\section{References}

1. Ledić D, Girotto D, Pal S, Kolbah B (2014) Risk factors for subdural bleeding in elderly population. Coll Antropol 38(4): 1195-1198.
2. Sambasivan M (1997) An overview of chronic subdural hematoma: Experience with 2300 cases. Surg Neuro 47(5): 418-422.

3. Crone KR, Lee KS, Davis CH (1985) Oculomotor palsy with pupillary sparing in a patient with chronic subdural hematoma. Surg Neurol 24(6): 668-670.

4. Phookan G, Cameron M (1994) Bilateral chronic subdural haematoma: an unusual presentation with isolated oculomotor nerve palsy. J Neurol Neurosurg Psychiatry 57(9): 1146.

5. Matsuda R, Hironaka Y, Kawai H, Park YS, Taoka T, et al. (2013) Unilateral oculomotor nerve palsy as an initial presentation of bilateral chronic subdural hematoma: case report. Neurol Med Chir (Tokyo) 53(9): 616-619.

6. Nakagawa H, Nakajima S, Nakajima Y, Furuta Y, Nishi O, et al. (1991) Bilateral oculomotor nerve palsies due to posterior cerebral arterial compression relieved by microvascular decompression-case report. Neurol Med Chir (Tokyo) 31(1): 45-48.

7. Saito R, Sugawara T, Mikawa S, Fukuda T, Kohama M, et al. (2008) Pupilsparing oculomotor nerve paresis as an early symptom of unruptured internal carotid-posterior communicating artery aneurysms-three case reports. Neuro Med Chir (Tokyo) 48(7): 304-306.

8. Odake G, Houri T (1990) Cavernous-carotid thrombosis and ocular motor paresis. Surg Neurol 34(5): 331-335.

Your next submission with JuniperPublishers will reach you the below assets

- Quality Editorial service

- Swift Peer Review

- Reprints availability

- E-prints Service

- Manuscript Podcast for convenient understanding

- Global attainment for your research

- Manuscript accessibility in different formats ( Pdf, E-pub, Full Text, Audio)

- Unceasing customer service

Track the below URL for one-step submission http://juniperpublishers.com/online-submission.php 